PATIK : Jurnal Hukum

https://ejournal.uhn.ac.id/index.php/patik

Volume 09 Nomor 01, April 2020 Page : 10 - 19

p-issn : 2086 - 4434

\title{
PERLINDUNGAN HUKUM TERHADAP KETIADAAN \\ AKSESIBILITAS PENYANDANG DISABILITAS SEBAGAI \\ PENUMPANG PESAWAT UDARA OLEH MASKAPAI PENERBANGAN DI INDONESIA DITINJAU DARI UU NOMOR 1 TAHUN 2009 TENTANG PENERBANGAN
}

\author{
Sherena Octaria, Roida Nababan, August Silaen \\ Fakultas Hukum, Universitas HKBP Nommensen \\ roidanababan@uhn.ac.id
}

\begin{abstract}
Abstrak
Tujuan penelitian ini ingin mengetahui siapa saja yang bertanggung jawab dalam pemenuhan kewajibanya sebagai pihak pengangkutan udara dan apa saja yang dapat dimintai dan menjadi hak penyandang disabilitas atas ketiadaan aksesibilitas (fasilitas umum) bagi para difabel dalam ruang lingkup penerbangan. Dalam penelitian ini pengumuplan data dan fakta menggunakan studi kepustakaan dalam pemecahan masalah. Hasil dari penelitian ini adalah pihak yang bertanggung jawab dalam pemberian ganti kerugian penyandang disabilitas adalah pihak pengangkutan udara yaitu maskapai penerbangan selaku pelaku usaha. Dalam undang-undang no. 8 tahun 1999 tentang perlindungan konsumen pada pasal 19 disebutkan bahwa setiap pelaku usaha bertanggung jawab memberi ganti rugi atas kerusakan, pencemaran, dan/ kerugian akibat mengkonsumsi barang dan/jasa yang dihasilkan atau diperdagangkan. Maka pihak maskapai penerbangan selaku pelaku usaha bertanggung jawab dalam pemberian ganti kerugian dikarenakan kelalaian yang menggunakan aksesibilitas khusus penyandang disabilitas yang tidak memumpuni menyebabkan tertinggalnya penumpang pesawat tersebut.
\end{abstract}

Kata Kunci : Penyandang Disabilitas, Penerbangan, Wanprestasi.

\begin{abstract}
The purpose of this study is to study who is responsible for fulfilling responsibility as an air carrier and what can be requested and become the right of persons with disabilities in the absence of accessibility (public facilities) for persons with disabilities in the supported service space. In proving this analysis the authors use research to obtain qualitative researchers departing from the data, utilizing existing theories as explanatory material, and concluding with "theories". In this research data and facts collection uses literature study in problem solving. The results of this study are the parties responsible for providing restitution for persons with disabilities is the air transport party, the airline as a business actor. Then in law no. 8 of 1999 about the consumer protection in article 19 states that each business actor is responsible for providing compensation for damage, pollution and / or losses from consuming goods and / services produced or traded. So the airline as a business actor is responsible for providing restitution due to negligence that uses special accessibility for persons with disabilities who are not qualified to cause the passengers to be left behind.
\end{abstract}

Keywords : Disability, Flight, Breach of Contract, Passengers 
PATIK : JURNAL HUKUM Vol : 09 No. 1, April 2020, Hal 10 - 19

\section{Pendahuluan}

Kemajuan dibidang penerbangan yang sangat pesat telah merubah wajah dan peta perkembangan perekonomian, mobilitas penduduk, dan pembangunan secara luas. Lalu lintas pesawat udara dan penumpang udara dilakukan melalui suatu bandar udara (airport). Bandar udara merupakan simpul penerbangan yang melayani kegiatan lalu lintas penumpang udara dan pesawat udara. Untuk melayani kegiatan pendaratan dan lepas landas pesawat udara disediakan landasan pacu. Untuk melayani kegiatan penumpang yang melakukan perjalanan udara (keberangkatan dan kedatangan) dibangunlah suatu terminal penumpang. Transportasi udara mempunyai peranan yang sangat penting dalam menyediakan jasa pelayanan transportasi untuk pengangkutan manusia dan barang antara bandar udara asal ke bandar udara tujuan yang berjauhan letaknya dalam suatu negara ataupun antar negara, menggunakan sarana pesawat udara melalui rute penerbangan. ${ }^{1}$

Penerbangan adalah satu kesatuan sistem yang terdiri atas pemanfaatan wilayah udara, pesawat udara, bandar udara, angkutan udara, navigasi penerbangan, keselamatan, dan keamanan, lingkungan hidup, serta fasilitias penunjang, dan fasilitas umum lainnya Permintaan jasa penerbangan dewasa ini sudah sangat meluas, bukan hanya melayani perjalanan antar kota besar, tetapi telah berkembang melayani perjalanan udara ke kotakota kecil yang tersebar di seluruh wilayah Indonesia. Masyarakat selaku pengguna jasa transportasi udara dalam hal ini di kategorikan ke dalam konsumen.

Masyarakat selaku konsumen dewasa ini sering berada pada posisi yang lemah, sebab tidak adanya perlindungan yang seimbang terhadap posisinya jika di hadapkan dengan pelaku usaha. Tidak jarang kerugian yang di timbulkan oleh pihak maskapai penerbangan terhadap masyarakat yang menggunakan jasa mereka untuk bepergian. Seperti delayed, masyarakat selaku konsumen dirugikan tidak hanya dari segi materi, namun juga dari segi waktu yang terbuang karena selisih waktu keberangkatan dan waktu kedatangan yang berbeda dari waktu yang telah dijadwalkan. Kerugian pada saat menggunakan jasa transportasi udara selama ini tidak hanya di alami oleh masyarakat pada umumnya, penyandang disabilitas pada saat menggunakan jasa transportasi udara juga selama ini kerap kali mengalami diskriminasi yang cukup merugikan mereka, seperti fasilitas publik yang tidak sesuai dengan kebutuhan konsumen penyandang disabilitas pada khususnya. $^{2}$

Anak ini dibantu oleh petugas training dan masalah timbul karena petugas tidak membawa radio komunikasi, sebab di informasikan lewat radio komunikasi bahwa pesawat yang hendak mengangkut anak laki-laki ini, dikatakan sudah dengan penumpang yang lengkap dan informasi itu baru diberitahukan pada saaat pesawat hendak take-off. Peristiwa itu bermula pada saat boarding. Saat anak laki-laki tersebut sudah melewati petugas Garuda Indonesia untuk disobek boarding pass-nya, namun karena Bandara Ngurah Rai Bali tidak aksesibel bagi pengguna kursi roda, maka sang anak dengan kursi rodanya harus turun tangga terlebih dahulu, naik bus, dan kemudian naik tangga lagi untuk masuk pesawat. Dalam kondisi itu tidak ada petugas, baik dari Garuda Indonesia maupun Bandara Ngurah Rai Bali itu sendiri yang membantu, sehingga ia tertinggal pesawat yang hendak ia naiki menuju Surabaya. ${ }^{3}$

Dalam kasus diatas, yang mana masih sangat kurangnya perhatian pemerintah baik pihak maskapai penerbangan maupun badan usaha pengangkutan niaga tersebut dalam memberikan pelayanan atau kewajibanya terhadap penyandang disabilitas hingga saat ini,

\footnotetext{
${ }^{1}$ Sakti AdjiAdisasmita. Penerbangan dan Bandar Udara, Yogyakarta: Graha Ilmu. 2013. Hlm. 3.

${ }^{2}$ Mariam Darus Badrulzaman. "Aneka Hukum Bisnis". Bandung: Alumni. 1994. hlm 47.

${ }^{3}$ https://www.viva.co.id/berita/nasional/666292-penumpang-disabilitas-telantar-bandara-itu-urusangaruda/ diakses pada tanggal 10 Februari 2020 Pukul 13.38 WIB
} 


\section{PATIK : JURNAL HUKUM Vol : 09 No. 1, April 2020, Hal 10 - 19}

dengan kata lain masih adanya sikap diskriminatif para pihak tersebut kepada penyandang disabilitas karena ketidak adanya aksesibilitas bagi beliau untuk menaiki pesawat tersebut dan timbulah miskomunikasi dan keterlambatan masuk pesawat terhadap anak penyandang disabilitas tersebut. Pada dasarnya penyandang disabilitas ialah seseorang yang harus di berikan perhatian dan perlakuan yang sama dalam hak nya sebagai penyandang disabilitas seperti yang dikatakan dalam Undang - Undang Nomor 8 tahun 2016 pada Pasal 1 ayat (1) tentang Penyandang Disabilitas bahwa "setiap orang yang mengalami keterbatasan fisik, intelektual, mental, dan/atau sensorik dalam jangka waktu lama yang dalam berinteraksi dengan lingkungan dapat mengalami hambatan dan kesulitan untuk berpartisipasi secara penuh dan efektif dengan warga negara lainnya berdasarkan kesamaan hak."

Hak-hak yang sama dimaksudkan dalam persoalan ini ialah hak penyandang disabilitas dalam pelayanan khusus terhadap dirinya yang memiliki keterbatasan dan ingin melakukan perjalanan menggunakan maskapai penerbangan selayaknya orang normal pada umumnya tanpa adanya sikap diskriminatif pihak maskapai maupun badan usaha niaga, yang mana telah tertulis di dalam Undang- undang No. 1 Tahun 2009 tentang penerbangan pada pasal 134 ayat (1) yang berisi bahwa "Penyandang cacat, lanjut usia, anak-anak di bawah usia 12 (dua belas) tahun, dan/atau orang sakit berhak memperoleh pelayanan berupa perlakuan dan fasilitas khusus dari badan usaha angkutan udara niaga."

Yang mana penyandang disabilitas perlu diberikan akses sendiri berupa fasilitas fasilitas pembantu agar dapat beraktivitas atau berkegiatan di dalam bandar udara secara fleksibel dan mandiri, serta memberikan kenyamanan pada seluruh pengguna jasa angkutan udara di bandar udara tanpa terkecuali. Perlakuan khusus tersebut dipandang sebagai upaya maksimalisasi penghormatan, pemajuan, perlindungan dan pemenuhan hak asasi manusia universal. Bentuk pelayanan publik kepada para penyandang disabilitas di bandar udara perlu diperhatikan secara khusus agar tidak terjadi lagi persoalan yang serupa dan mengakibatkan kerugian terhadap salah satu pihaknya yaitu si penyandang disabilitas (konsumen) itu sendiri.

Karena menyikapi kenyataan yang ada para penyandang disabilitas mengalami kesulitan dan menyebabkan kerugian dalam hal ini yang disebabkan tidak adanya ruang gerak mereka yang memadai. Selanjutnya berdasarkan uraian diatas mengenai tindakan diskriminasi terhadap konsumen penyandang disabilitas, pada akhirnya mendorong penulis untuk mengkaji lebih mendalam lagi mengenai bagaimana bentuk perlindungan terhadap konsumen penyandang disabilitas angkutan udara. Dengan berdasarkan pada uraian-uraian tersebut diatas, maka dapat dirumuskan problematikanya sebagai berikut :

1. Bagaimana kah pertanggung jawaban terhadap ketiadaan aksesibilitas untuk penyandang disabilitas?

2. Tuntuan apa saja kah yang dapat dimintai pertanggung jawaban sebagai akibat dari ketiadaan aksesibilitas untuk penyandang disabilitas?

\section{Tinjauan Pustaka}

Menurut Pasal 1 angka 2 Undang-undang Nomor 22 Tahun 2009 Tentang Lalu Lintas dan Angkutan Jalan, angkutan adalah perpindahan orang dan/atau barang dari satu tempat ke tempat lain dengan menggunakan kendaraan di ruang lalu lintas jalan. ${ }^{4}$ Berawal dari kata 'angkut' ini kemudian dikembangkan lebih lanjut menjadi kata 'pengangkutan' dan kata transportasi yang mengangkut. Contohnya seperti pengangkutan kereta api, pengangkutan kapal, pengangkutan bus, dan lain sebagainya. Menurut Abdul Kadir Muhammad, pengertian pengangkutan berasal dari kata "angkut" yang memiliki arti

\footnotetext{
${ }^{4}$ Undang-undang Nomor 22 Tahun 2009, tentang “Lalu Lintas dan Angkutan Jalan”, Bab I, Pasal 1, Ayat 3.
} 
mengangkat atau membawa, memuat dan membawa atau mengirim. ${ }^{5}$ Pengertian lain dari pengangkutan adalah kegiatan pemindahan orang dan/atau barang dari suatu tempat ke tempat lain baik melalui angkutan darat, angkutan perairan, maupun angkutan udara dengan menggunakan alat angkutan. ${ }^{6}$ Hukum pengangkutan juga dapat didefinisikan sebagai sebuah perjanjian timbal-balik, pada mana pihak pengangkut mengikat diri untuk menyelenggarakan pengangkutan barang dan/atau orang ke tempat tujuan tertentu, sedangkan pihak lainnya (pengirim-penerima;pengirim atau penerima; penumpang) berkeharusan untuk menunaikan pembayaran biaya tertentu untuk pengangkutan tersebut. ${ }^{7}$ Sedangkan, pengangku tan menurut R. Soekardono berisikan bahwa pengangkutan ialah perpindahan tempat, baik mengenai benda-benda maupun mengenai orang-orang, karena perpindahan itu mutlak perlu untuk mencapai dan meninggikan manfaat serta efisien. Proses dari pengangkutan itu merupakan gerakan dari tempat asal dari mana kegiatan angkutan itu dimulai sampai ke tempat tujuan dimana angkutan itu diakhiri. ${ }^{8}$

Pihak- pihak dalam pengangkutan penumpang udara dapat dikatakan sebagai subjek hukum dalam pengangkutan subjek hukum disebut sebagai pendukung hak dan kewajiban. Dalam Pasal 1 Ayat 29 Undang-Undang Nomor 1 Tahun 2009 Tentang Penerbangan, perjanjian pengangkutan udara adalah perjanjian antara pengangkut dan pihak penumpang dan/atau pengirim kargo untuk mengangkut penumpang dan/atau kargo dengan pesawat udara, dengan imbalan bayaran atau dalam bentuk imbalan jasa yang lain.

Dalam pengangkutan penumpang udara subjek atau pihak dari hubungan hukum tersebut yaitu: ${ }^{9}$

1. Pengangkut (carrier)

Dalam perjanjian pengangkutan penumpang, pihak yang berkewajiban memberikan pelayanan jasa angkutan kepada penumpang dan berhak atas penerimaan pembayaran tarif (ongkos) angkutan sesuai yang telah ditetapkan. Terbagi menjadi dua yaitu : a. Badan Usaha Angkutan Udara adalah badan usaha milik negara, badan usaha milik daerah, atau badan hukum Indonesia berbentuk perseroan terbatas atau koperasi, yang kegiatan utamanya mengoperasikan pesawat udara untuk digunakan mengangkut penumpang, kargo, dan/atau pos dengan memungut pembayaran. Yang disebut juga sebagai Maskapai Penerbangan.Menurut R. S. Damardjati, ${ }^{10}$ maskapai penerbangan adalah perusahaan milik swasta atau pemerintah yang khusus menyelenggarakan pelayanan angkutan udara untuk penumpang umum baik yang berjadwal (schedule service/regular flight) maupun yang tidak berjadwal (non schedule service). Penerbangan berjadwal menempuh rute penerbangan berdasarkan jadwal waktu, kota tujuan maupun kota - kota persinggahan yang tetap. Sedangkan penerbangan tidak berjadwal sebaliknya, dengan waktu, rute, maupun kota - kota tujuan dan persinggahan bergantung kepada kebutuhan dan permintaan pihak penyewa. Sedangkan, menurut Widadi A. Suwarno, berpendapat bahwa maskapai penerbangan atau airlines perusahaan penerbangan yang menerbitkan dokumen penerbangan untuk mengangkut penumpang beserta bagasinya, barang kiriman (kargo), dan benda pos (mail) dengan pesawat udara. ${ }^{11}$. b. Badan Usaha Bandar Udara adalah badan usaha milik negara, badan usaha milik daerah, atau badan hukum Indonesia berbentuk perseroan terbatas atau koperasi, yang

\footnotetext{
${ }^{5}$ Abdul Kadir Muhammad, Hukum Pengangkutan Darat, Laut, dan Udara, Bandung, PT. Citra Aditya Bakti, 1991, hlm 19.

${ }^{6}$ Hasim Purba, Hukum Pengangkutan di Laut, Medan, Pustaka Bangsa Press, 2005, Hlm. 4.

${ }^{7}$ Sution Usman Adji, dkk, "Hukum Pengangkutan Di Indonesia", Jakarta: Rineka Cipta, 1990, hal.5-7.

${ }^{8}$ R. Soekardono, Hukum Dagang Indonesia, Jakarta : CV Rajawali, 1981,Hlm. 5.

${ }^{9}$ http://soegeng-poernomo.blogspot.com/2015/03/pihak-pihak-terkaitdalampengangkutan.html/,diakses pada Tanggal 24 April 2020 Pukul 14.04 WIB

${ }^{10}$ Damardjati, R.S. "Istilah-Istilah Dunia Pariwisata”. Ghalia Indonesia. Jakarta, 2001.

${ }^{11}$ A.Suwarno. Widadi. "Tata operasi Darat”. Grasindo, Jakarta. 2001
} 
kegiatan utamanya mengoperasikan bandar udara untuk pelayanan umum. ${ }^{12}$ Menurut Sakti Adji Adisasmita Bandar udara adalah lapangan terbang yang dipergunakan untuk mendarat dan lepas landas pesawat udara, naik turun penumpang dan atau bongkar muat kargo dan atau pos, serta dilengkapi dengan fasilitas keselamatan penerbangan dan sebagai tempat perpindahan antar moda transportasi. ${ }^{13}$

2. Penumpang (passanger)

Penumpang adalah pihak yang berhak mendapatkan pelayanan jasa angkutan penumpang dan berkewajiban untuk membayar tarif (ongkos) angkutan sesuai yang ditetapkan. Menurut perjanjian pengangkutan, penumpang mempunyai status, yaitu sebagai subjek karena dia adalah pihak dalam perjanjian dan sebagai objek karena dia adalah muatan yang diangkut. Pihak pengangkut dalam pengangkutan udara niaga merupakan pendukung dari hak dan kewajiban masing-masing para pihak, dan setiap masing-masing pihak harus melaksanakan kewajibannya serta mendapatkan haknya, sehingga dalam proses penyelenggaraan pengangkutan tersebut berjalan dengan semestinya. Pihak pengangkut dapat berstatus badan hukum, persekutuan bukan badan hukum, atau perseorangan. Sedangkan pihak penumpang dalam pengangkutan udara niaga selalu berstatus perseorangan. ${ }^{14}$

Undang-Undang Indonesia Nomor 4 tahun 1997 Tentang Penyandang Cacat menjelaskan bahwa Penyandang Cacat adalah setiap orang yang mempunyai kelainan fisik dan/ atau mental, yang dapat mengganggu atau merupakan rintangan dan hambatan baginya untuk melakukan kegiatan secara selayaknya, yang terdiri dari: ${ }^{15}$ Kelainan fisik adalah kecacatan yang mengakibatkan gangguan pada fungsi tubuh antara lain gerak tubuh, penglihatan, pendengaran, dan kemampuan bicara. Kelainan mental adalah kelainan dalam tingkah laku, baik kelainan bawaan maupun akibat dari penyakit. Kelainan fisik dan mental adalah keadaan seseorang yang menyandang dua jenis kelainan sekaligus. Beberapa asas tersebut diantaranya:

1. Kepentingan Umum

Yaitu, pemberian pelayanan tidak boleh mengutamakan kepentingan pribadi dan/atau golongan.

2. Kepastian Hukum

Yaitu,jaminan terwujudnya hak dan kewajiban dalam penyelenggaraan pelayanan.

3. Kesamaan Hak

Yaitu, pemberian pelayanan tidak membedakan suku, ras, agama, golongan, gender dan status ekonomi

4. Keseimbangan Hak dan Kewajiban

Yaitu, pemenuhan hak harus sebanding dengan kewajiban yang harus dilaksanakan, baik oleh pemberi maupun penerima pelayanan.

5. Keprofesionalan

Yaitu, pelaksanaan pelayanan harus memiliki kompetensi yang sesuai dengan bidang tugas.

6. Partisipatif

${ }^{12}$ R.I., Undang-undang Nomor 01 Tahun 2009, tentang “Penerbangan”, Bab I, Pasal 1, Ayat 20 \&

${ }^{13}$ Adji. Sakti. Adisasmita. Op. cit Hal. 98

${ }^{14}$ http://soegeng-poernomo.blogspot.com/2015/03/pihak-pihak-terkait-dalam-pengangkutan.html Diakses pada Tanggal 06 Mei 2020 Pukul 13.49 Wib

${ }^{15}$ Peraturan Pemerintah Nomor 43 Tahun 1998 Tentang "Upaya Peninggkatan Kesejahteraan Sosial Penyandang Cacat.", 


\section{PATIK : JURNAL HUKUM Vol : 09 No. 1, April 2020, Hal 10 - 19}

Yaitu, peningkatan peran serta masyarakat dalam penyelenggaraan pelayanan dengan memperhatikan aspirasi, kebutuhan dan harapan masyarakat.

7. Persamaan perlakuan/tidak diskriminatif

Yaitu, setiap warga Negara berhak memperoleh pelayanan yang adil.

8. Keterbukaan

Setiap penerima pelayanan dapat dengan mudah mengakses dan memperoleh informasi mengenai pelayanan yang diinginkan.

9. Akuntabilitas

\section{Metode}

Fokus yang akan di kaji dalam penelitian ini ialah bagaimanakah pertanggung jawab atas ketiadaan aksesibilitas penumpang pesawat yaitu penyandang disabilitas. Dan bagaimana tuntutan yang berlaku untuk pihak yang bertanggung jawab dalam persoalan ketiadaan aksesibilitas ini. Dan tujuannya berguna untuk mengetahui siapa yang dapat bertanggung jawab dengan menggunakan sumber-sumber data dibawah ini. ${ }^{16}$ Pengumpulan bahan hukum diperoleh dengan melakukan studi kepustakaan, yaitu dengan mempelajari bahan hukum primer dan sekunder. Analisis Data Data yang diperoleh dalam penelitian kepustakaan diolah dan dianalisis secara kualitatif, artinya analisis dengan menggunakan ukuran kualitatif. Data yang diperoleh dari kepustakaan secara tertulis, kemudian diarahkan, dibahas, dan diberi penjelasan dengan ketentuan yang berlaku, kemudian disimpulkan dengan metode deduktif, yaitu menarik kesimpulan dari hal yang umum ke hal yang khusus.

\section{Pembahasan Dan Hasil}

Dalam praktek nya, kesepakatan tersebut tidak lah sesuai dengan apa yang sudah di perjanjikan yaitu penumpang diangkut oleh pihak pengangkut merupakan salah satu pihak pengangsampai ke tempat tujuan. Maka dari itu, yang menjadi Hak Penumpang ialah mendapatkan pelayanan hingga sampai ke tempat yang ia tuju melalui layanan transportasi udara tersebut dengan membayarkan uang tiket pesawat, sesuai dalam hak nya di dalam Undang-undang penerbangan No. 1 Tahun 2009 di dalam pasal 134 ayat 1 yaitu Penyandang cacat, lanjut usia, anak-anak di bawah usia 12 (dua belas) tahun, dan/atau orang sakit berhak memperoleh pelayanan berupa perlakuan dan fasilitas khusus dari badan usaha angkutan udara niaga. Akan tetapi Hak tersebut hilang karena penumpang yang kebetulan sebagai penyandang cacat (disabilitas) tidak mendapatkan hak nya dikarenakan ketiadaan aksesibilitas (khusus penyandang cacat) yang menyebabkan ia tertinggal pesawat. Akan tetapi menurut Endang Saefullah Wirapradja menerangkanbahwa ada lima jenis pertanggungjawaban dalam hukum pengangkutan.Antara lain :

Pertama, based on fault liability, yaitu konsep dasar yang biasa ditemui dalam ranah hukum perdata. Dalam sistem hukum Indonesia, penggunaan konsep ini tertuang jelas dalam Pasal 1365 Kitab Undang-Undang Hukum_Perdata ("KUH Perdata") yang berbunyi bahwa, tiap perbuatan yang melanggar hukum dan membawa kerugian kepada orang lain, mewajibkan orang yang menimbulkan kerugian itu karena kesalahannya untuk menggantikan kerugian tersebut. Dalam hukum pengangkutan, pihak yang dapat dikenai tanggung gugat secara hukum tidak terbatas pada pihak pengangkut saja, namun termasuk juga setiap perbuatan yang dilakukan pihak lain yang terlibat dalam segala proses

\footnotetext{
${ }^{16}$ Bambang Sunggono. Metode Penelitian Hukum. Jakarta: Raja Grafindo Persada. 1997.
} 
penyelenggaraan kegiatan pengangkutan, seperti awak kapal atau karyawan yang bekerja di sebuah perusahaan pengangkutan tersebut ${ }^{17}$

Berdasarkan prinsip ini, beban pembuktian ada pada pihak penumpang atau pengirim barang yang harus dapat memenuhi unsur kesalahan, kerugian, dan adanya hubungan kausalitas antara kesalahan dan kerugian itu. ${ }^{18}$

Namun prinsip ini tidak dapat diterapkan, karena adanya kemungkinan pihak penumpang atau pengirim barang tidak mampu membuktikan kesalahan, karena keterbatasan pengetahuan dalam kegiatan penerbangan. ${ }^{19}$ Kedua, presumption of liability, yaitu beban pembuktian tidak berada pada pihak penumpang, melainkan di pihak pengangkut. Beban pembuktian ini sering dikenal dengan beban pembuktian terbalik di mana maskapai selalu dianggap bersalah dan wajib membayar ganti kerugian tanpa perlu adanya pembuktian oleh penumpang terlebih dahulu. ${ }^{20}$ Ketiga, limitation of liability yang memberikan perlindungan kepada pihak pengangkut terkait kemungkinan penuntutan besaran ganti rugi yang tidak terbatas. ${ }^{21}$ Keempat, presumption of nonliability, yaitu prinsip di mana pengangkut tidak perlu untuk selalu bertanggung gugat sepenuhnya atau bahkan tidak perlu bertanggung gugat sama sekali, kecuali memang adanya bukti bahwa kerugian tersebut memang disebabkan oleh pengangkut. Pembuktian jenis ini bertujuan untuk membuktikan sampai sejauh mana pengangkut dapat bertanggung gugat. Kelima, liability without fault yang merupakan penyimpangan dari prinsip tanggung gugat yang menyatakan bahwa unsur kesalahan yang menyebabkan kerugian merupakan hal yang diperlukan dalam setiap penuntutan ganti rugi.

Merujuk pada prinsip diatas yang dapat menjadi bangku atau sandaran pihak penumpang pada prinsipnya ialah liability without fault yang merupakan penyimpangan dari prinsip tanggung gugat yang menyatakan bahwa unsur kesalahan yang menyebabkan kerugian merupakan hal yang diperlukan dalam setiap penuntutan ganti rugi. Menurut Endang Saefullah Wirapradja Menerangkan bahwa unsur kesalahan tidak relevan untuk dipermasalahkan, karena yang terpenting bila seseorang menderita kerugian atas perbuatan orang lain, maka dia secara mutlak harus bertanggung gugat. ${ }^{22}$ Pihak Badan usaha Angkutan Udara ikut andil dan berhak bertanggung jawab atas ketidak terangkutnya penumpang disabilitas tersebut di lihat dari prinsip diatas walau tidak diatur di dalam Undang-undang tentang tanggung jawab pengangkutan udara No. 77 Tahun 2011.

Pihak bandar udara memiliki tanggung jawab dalam pemenuhan kebutuhan para penumpang dalam mendapatkan pelayanan pemenuhan kebutuhan penunjang dalam transportasi udara tersebut, merujuk kepada Undang-undang No. 1 Tahun 2009 Tentang Penerbangan yang mana terdapat pada pasal 219 mengenai fasilitas bandara dimana pada ayat 1 dijelaskan bahwa Setiap badan usaha bandar udara atau unit penyelenggara bandar udara wajib menyediakan fasilitas bandar udara yang memenuhi persyaratan keselamatan dan keamanan penerbangan, serta pelayanan jasa bandar udara sesuai dengan standar pelayanan yang ditetapkan.

Ganti rugi dalam hukum perdata dapat timbul dikarenakan wanprestasi akibat dari suatu perjanjian atau dapat timbul dikarenakan oleh Perbuatan Melawan Hukum itu sendiri. Secara prinsip dalam KUHPerdata pasal 1365 dinyatakan bahwa "setiap perbuatan

\footnotetext{
${ }^{17}$ Adhy Riadhy Arafah dan Sarah Amalia Nursani. 2019. "Pengantar Hukum Penerbangan Privat."

Jakarta: Prenadamedia Group. Hlm 24

${ }^{18}$ Ibid., hlm 24-25

${ }^{19}$ Ibid., hlm. 25

${ }^{20}$ Ibid., hlm.26

${ }^{21}$ Ibid., hlm. 27

${ }^{22}$ Ibid., hlm. 29
} 


\section{PATIK : JURNAL HUKUM Vol : 09 No. 1, April 2020, Hal 10 - 19}

melawan hukum yang oleh karena itu menimbulkan kerugian pada orang lain, mewajibkan orang yang karena kesalahannya menyebabkan kerugian tersebut mengganti kerugian" 23 Maka muncul lah tuntutan atas itu, Ganti rugi yang muncul dari wanprestasi adalah jika ada pihak-pihak dalam perjanjian yang tidak melaksanakan komitmentnya yang sudah dituangkan dalam perjanjian, maka menurut hukum dia dapat dimintakan tanggung jawabnya, jika pihak lain dalam perjanjian tersebut menderita kerugian karenanya. ${ }^{24}$

Adanya kerugian bagi korban juga merupakan syarat agar gugatan berdasarkan Pasal 1365 KUHPerdata dapat dipergunakan. ${ }^{25}$ Unsur kesalahan yang dimaksudkan ialah bahwa adanya kerugian yang diderita oleh pihak penumpang selaku penyandang cacat (disabilitas) dalam melakukan perjalananya dengan maskapai penerbangan dengan bukti bahwa membeli sejumlah tiket pesawat maskapai tersebut. Adanya unsur kesalahan disini ialah keadaan dimana penumpang kesulitan dalam melakukan kegiatanya di area wilayah bandar udara dengan keterbatasanya yang menyebabkan ia tertinggal oleh maskapai penerbangan yang ia tumpangi.

Biaya adalah setiap uang (termasuk ongkos) yang harus dikeluarkan secara nyata oleh pihak yang dirugikan, dalam hal ini sebagai akibat dari adanya tindakan wanprestasi. Sedangkan yang dimaksud dengan "rugi" adalah keadaan merosotnya (berkurangnya) nilai kekayaan kreditor sebagai akibat dari adanya wanprestasi dari pihak debitur.sedangkan yang dimaksud dengan "bunga" adalah keuntungan yang seharusnya diperoleh tetapi tidak jadi diperoleh oleh pihak kreditur karena adanya tindakan wanprestasi dari pihak debitur. ${ }^{26}$

Pemberian suatu ganti rugi sebagai akibat dari tindakan wanprestasi dari suatu perjanjian, dapat diberikan dengan berbagai kombinasi antara lain pemberian ganti rugi (berupa rugi, biaya dan bunga), pelaksanaan perjanjian tanpa ganti rugi, pelaksanaan perjanjian plus ganti rugi, pembatalan perjanjian timbal balik tanpa ganti rugi, pembatalan perjanjian timbal balik plus ganti rugi. Selanjutnya dalam literature dan yurisprudensi dikenal pula beberapa model ganti rugi atas terjadinya wanprestasi, yaitu sebagai berikut: ${ }^{27}$

1. Ganti rugi yang ditentukan dalam perjanjian.

Yang dimaksudkan dengan ganti rugi yang ditentukan dalam perjanjian adalah suatu model ganti rugi karena wanprestasi dimana bentuk dan besarnya ganti rugi tersebut sudah ditulis dan ditetapkan dengan pasti dalam perjanjian ketika perjanjian ditanda tangani, walaupun pada saat itu belum ada wanprestasi.

2. Ganti rugi ekspektasi.

Ganti rugi dalam bentuk ekspektasi adalah suatu bentuk ganti rugi tentang hilangnya keuntungan yang diharapkan (di masa yang akan datang), seandainya perjanjian tersebut tidak wanprestasi. jadi, dalam hal ini, pihak yang dirugikan karena wanprestasi ditempatkan seolah olah tidak terjadi wanprestasi dengan berbagai keuntungan yang akan didapatkannya.

3. Pergantian biaya.

Yang dimaksud dengan ganti rugi berupa pergantian biaya adalah ganti rugi dalam bentuk pergantian seluruh biaya yang telah dikeluarkan oleh salah satu pihak yang harus dibayar oleh pihak lain, yang telah melakukan

\footnotetext{
${ }^{23}$ https://manplawyers.co/2017/10/03/ganti-kerugian-adalah-hak/ Diakses pada Tanggal 15 Juni 2020 Pukul 12.42 Wib.

${ }^{24}$ Fuady.Munir, 2014, “Konsep Hukum Perdata", Cetakan Pertama, Jakarta: PT Raja Grafindo Persada. Hal 223

${ }^{25}$ Adhy Riadhy Arafah dan Sarah Amalia Nursani. Op. Cit hlm.13.

${ }^{26}$ Fuady.Munir, Op.cit hlm. 224.

${ }^{27}$ Ibid hlm. 224-228.
} 


\section{PATIK : JURNAL HUKUM Vol : 09 No. 1, April 2020, Hal 10 - 19}

wanprestasi terhadap perjanjian tersebut. Karena perhitungan biaya yang telah dikeluarkan tersebut umumnya dilakukan dengan melihat kepada bukti-bukti pengeluaran berupa kwitansi-kwitansi.

4. Restitusi.

Ganti rugi berupa restitusi adalah suatu model ganti rugi yang juga menempatkan perjanjian pada posisi seolah-olah sama sekali tidak terjadi perjanjian. Akan tetapi dalam hal ini, yang harus dilakukan adalah mengembalikan seluruh nilai tambah dalam wujudnya semula yang telah diterima oleh salah satu pihak atau kedua belah pihak dari pihak yang satu ke pihak yang lainya. Nilai tambah yang dimaksud disini suatu nilai lebih yang telah diterima oleh para pihak seabgai akibat dari pelaksanaan perjanjian, nilai tambah tersebut harus dikembalikan dalam bentuk semula sebagai salah satu wujud dari ganti rugi.

5. Quantum meruit.

Quantum Meruit merupakan model ganti rugi yang hampir mirip dengan model restitusi yang membedakan adalah nilai tambah yang harus dikembalikan dalam model ini bukan nilai tambah dalam wujud aslinya melainkan harga dari nilai tambah yang telah diterima, karena bendanya dalam bentuk asli sudah tidak dalam posisi untuk dikembalikan lagi. Pemberian ganti rugi berupa pelaksanaan perjanjian adalah kewajiban melaksanakan perjanjian meskipun sudah terlambat, dengan atau tanpa ganti rugi.

Dalam hal ini, dapat kita lihat bahwa jika akesibilitas yang digunakan tidak sesuai dengan yang diperjanjikan pada awalnya (sesuai dengan Undang-Undan No. 1 Tahun 2009 pasal 134 tentang pemenuhan hak disabilitas), hal tersebut mengakibatkan penumpang tertinggal pesawat karena aksesibilitas untuk penyandang cacat tidak ada, maka mutlak telah terjadinya pelanggaran hak konsumen. Dimana dalam Pasal 7 huruf g Undangundang Perlindungan Konsumen, pelaku usaha juga berkewajiban untuk memberi kompensasi, ganti rugi dan/atau penggantian apabila barang dan/atau jasa yang diterima atau dimanfaatkan tidak sesuai dengan perjanjian. ${ }^{28}$ Barang/jasa yang dimaksud dalam kalimat tersebut dapat direferensikan sebagai aksesibilitas atau fasilitas bagi para penyandang cacat tersebut yang tidak sesuai dengan apa yang sudah diperjanjikan. Dimana, jika pengangkut menjual tiket pesawat tanpa adanya pengecualian bagi siapa saja yang dapat menaiki pesawatnya atau tidak adanya perjanjian tertulis tentang syarat dan kondisi yang berlaku mengenai hal itu. Maka otomatis pihak pelaku usaha yaitu pengangkut wajib bertanggung jawab menyediakan fasilitas kebutuhan bagi para penyandang cacat tersebut selama berada diwilayah penerbangan itu sendiri tanpa terkecuali karena merupakan satu kesatuan dari pemenuhan kewajiban tersebut.

\section{Kesimpulan Dan Saran}

Bahwa ranah tersebut memang tanggung jawab pihak Bandar udara selaku pemberi fasilitas dan pelayanan sarana dan prasarana di wilayah Bandar udara. Akan tetapi tuntutan tersebut tidak dapat dimintai pertanggung jawaban karena belum ada peraturan khusus kepada pihak bandara melainkan hanya sanksi administratif atas pelanggaran ketiadaan aksesibilitas tersebut terhadap pihak bandara saja bukan untuk para konsumen. Dimaksudkan agar mencari tahu mengenai bukan siapa yang harus di salahkan, melainkan apa yang dapat menjadi hak penumpang (penyandang cacat) untuk memperoleh keadilan

\footnotetext{
${ }^{28}$ https://www.hukumonline.com/klinik/detail/ulasan/lt52f391f92aaba/langkah-hukum-jika-barangyang-diberikan-penjual-tidak-lengkap Diakses pada Tanggal 26 Juni 2020 Pukul 17.50 Wib.
} 
yang sebaik-baiknya sebagaimana diatur dalam Undang-undang No. 1 Tahun 2009 Tentang Penerbangan pada Pasal 134 tersebut.

Tuntutan yang dapat dimintai dari ketiadaan aksesibilitas tersebut ialah berupa ganti kerugian. Ganti kerugian di golongan menurut Kitab Undang-undang Hukum Perdata pada pasal 1239-1243 mengatakan bahwa ada 3 jenis ganti rugi yaitu biaya, rugi, bunga. Dan dijelaskan kembali menurut fuady munir dalam konsep hukum perdata ada beberapa kategori dalam pergantian ganti rugi tersebut yaitu :

\section{DAFTAR PUSTAKA}

\section{Buku}

Adisasmita, Sakti Adji. 2013. Penerbangan dan Bandar Udara. Yogyakarta: Graha Ilmu. Adji, Sution Usman. dkk. 1990. Hukum Pengangkutan Di Indonesia. Jakarta: Rineka Cipta.

Amardjati, R.S. 2001. Istilah-Istilah Dunia Pariwisata. Jakarta: Ghalia Indonesia.

Arafah, Adhy Riadhy dan Sarah Amalia Nursani. 2019. Pengantar Hukum Penerbangan Privat. Jakarta: Prenadamedia Group.

Badrulzaman, Mariam Darus. 1994. Aneka Hukum Bisnis. Bandung: Alumni.

Black, J.A. 1981. Urban Transport Planning: Theory and Practice. London: Cromm Helm.

Kartini, Kartono. 2001. Tentang Patologi Sosial, Jilid I. Jakarta : Raja Grafindo Persada.

Munir, Fuady. 2014. Konsep Hukum Perdata, Cetakan Pertama. Jakarta: PT. Raja Grafindo Persada.

Purba, Hasim. 2005. Hukum Pengangkutan di Laut. Medan : Pustaka Bangsa Press.

Soekardono, R. 1981. Hukum Dagang Indonesia. Jakarta : CV Rajawali.

Subekti, R. 2013. Kitab Undang-undang Hukum Perdata. Jakarta : PT. Pradnya Paramita.

Sunggono, Bambang. 1997. Metode Penelitian Hukum. Jakarta: Raja Grafindo Persada.

Widadi, A.Suwarno. 2001. Tata Operasi Darat. Jakarta : Grasindo.

\section{Peraturan PerUndang- Undangan}

Undang-undang Nomor 01 Tahun 2009, Tentang "Penerbangan".

Undang-undang Nomor 22 Tahun 2009 Tentang "Lalu Lintas dan Angkutan Jalan".

Undang-undang Nomor 08 Tahun 2016 Tentang "Penyandang Disabilitas".

Undang-undang Nomor 08 Tahun 1999 Tentang "Perlindungan Konsumen ".

Undang-undang Nomor 25 Tahun 2009 Tentang "Pelayanan Publik ".

Peraturan Pemerintah RI Nomor 43 Tahun 1998 Tentang "Upaya Peninggkatan Kesejahteraan Sosial Penyandang Cacat."

Peraturan Menteri RI Nomor 77 Tahun 2011 Tentang "Tanggung Jawab Pengangkut Angkutan Udara”. 